\title{
Crystal Structure, Hirshfeld Surface Analysis, Quantum Mechanical Study \\ and Spectroscopic characterization of the non-centrosymmetric
}

\section{coordination compound bis(4-fluoroaniline)dichloridozincate}

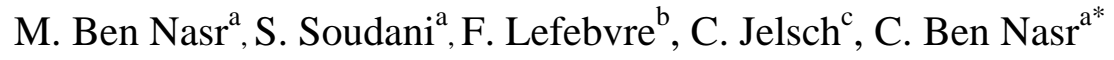 \\ a'Laboratoire de Chimie des Matériaux, Faculté des Sciences de Bizerte, 7021 Zarzouna, \\ Tunisie. \\ baboratoire de Chimie Organométallique de Surface (LCOMS), Ecole Supérieure de Chimie \\ Physique Electronique, 69622 Villeurbanne Cedex, France. \\ ${ }^{\mathrm{c}} \mathrm{CRM}^{2}$, CNRS, Institut Jean Barriol, Université de Lorraine, Vandoeuvre les Nancy CEDEX, \\ France.
}

\begin{abstract}
The $\mathrm{Zn}(\mathrm{II})$ complex with the monodentate ligand 4-fluoroaniline, $\mathrm{ZnCl}_{2}\left(\mathrm{C}_{6} \mathrm{H}_{4} \mathrm{FNH}_{2}\right)_{2}$, has been prepared and characterized by single crystal X-ray diffraction, solid state nuclear magnetic resonance, infrared spectroscopy and differential scanning calorimetry. The $\mathrm{Zn}$ (II) ion is tetracoordinated by two nitrogen atoms of two monodentate 4-fluoroaniline ligands and two chlorine atoms. In the molecular arrangement, the $\mathrm{ZnCl}_{2}\left(\mathrm{C}_{6} \mathrm{H}_{4} \mathrm{FNH}_{2}\right)_{2}$ entities are interconnected via $\mathrm{N}-\mathrm{H} \cdots \mathrm{Cl}$ hydrogen bonds to form layers parallel to the $(a, b)$ plane. The nature and proportion of contacts in the crystal packing were investigated through the Hirshfeld surfaces. The crystal is mainly maintained by electrostatic attractions $\mathrm{Cl}^{-} \ldots \mathrm{H}-\mathrm{N}$ and by extensive hydrophobic contacts as revealed by the Hirshfeld 2D fingerprint plots and statistical analysis. The ${ }^{13} \mathrm{C}$ and ${ }^{19} \mathrm{~F}$ CP-MAS NMR spectra are in agreement with the X-ray structure and confirm the phase purity of the crystalline sample. The vibrational absorption bands were identified by infrared spectroscopy. A calorimetric study shows that the title compound is stable until $262.5^{\circ} \mathrm{C}$.
\end{abstract}


Keywords: X-ray diffraction; CP-MAS NMR; XRPD; Hirshfeld surface analysis, Quantum; Calorimetric study

\section{Introduction}

Over the last 20 years, there has been an active and vibrant research into the development of metal-organic coordination materials, owing to their potentially useful properties [1-4]. These materials, which combine the properties of an inorganic component (e.g. chemical or thermal stability) with those of an organic molecular component within one scale, have interesting chemical and physical properties, which are manifested in their crystal structures [5]. The solid-state packing in these materials can be quite varied and is directed by the interactions present between the components constituting the crystalline compounds. Such interactions include van der Waals interactions, electrostatic interactions, hydrogen bonding, and $\pi-\pi$ interactions. In this area, polynuclear $\mathrm{d}^{10}$-metal complexes have been found to exhibit important structural and photoluminescent properties [6].

Design and fine-tuning of ligands are, together with the choice of metal, the most important aspects of coordination chemistry. Among ligands commonly used in coordination chemistry, nitrogen-containing ligands form an extremely widely used class, thanks to their facile synthesis, and their easily tunable steric and electronic properties [7, 8]. They are known to be versatile ligands, capable of generating a variety of molecular architectures and coordination polyhedrons [9-11]. The metal complexes of such ligands have been extensively used as biological probes [12], DNA cleavage agents [13], catalysts [14, 15], sensing materials [16, 17] or corrosion inhibitors [18]. The coordination chemistry of nitrogen coordinated ligands has also received a lot of attention because of their relevance to biological systems [19]. 
As a part of our continued involvement in the investigation of transition metal complexes of nitrogen-containing ligands [20-24], we report here the synthesis, crystal structure, investigation of intermolecular contacts by Hirshfeld surface analysis, XRPD, solid state NMR, IR spectroscopic characterization and differential scanning calorimetric analysis of bis(4-fluoroaniline)dichloridozincate, a chiral organic-inorganic network supported by hydrogen bonding interactions. It is worth to note that aniline based compounds such as the ligand employed here are used in many industries including dye and agrochemical by further functionalization and as pigments [25]. Most aromatic amines are however at least potentially carcinogenic and hazardous waste created in industry and are of substantial environmental impact $[26,27]$.

\section{Experimental}

2.1. Chemical preparation. A solution of $\mathrm{ZnCl}_{2}(27.2 \mathrm{mg}, 0.2 \mathrm{mmol})$ in water was added dropwise to a solution of 3-fluoroaniline $(24.2 \mathrm{mg}, 0.2 \mathrm{mmol})$ in ethanol $(6 \mathrm{~mL})$. After stirring for $30 \mathrm{~min}$, the mixture was filtered. Crystals suitable for X-ray analysis were obtained after five days by slow evaporation of the filtrate at room temperature (yield $=87 \%$ ). Anal. Calc.: C, $40.16 \%$; H, 3.34; N, $7.81 \%$. Found: C, 40.25; H, 3.27; N, $7.93 \%$.

2.2. Investigation techniques. The characterization of the title compound was carried out by X-ray diffraction, solid state NMR, IR spectroscopy, X-ray powder diffraction, Hirshfeld Surface Analysis and Differential Scanning Calorimetry measurements.

2.2.1. X-ray single crystal structural analysis. Single crystals were carefully selected under a microscope and mounted on a Mitegen micromesh mount with the help of a trace of mineral oil. X-ray diffraction data were collected at $100 \mathrm{~K}$ on a Bruker AXS APEXII CCD 
diffractometer. The unit cell was determined, the data collected, integrated and corrected for absorption and other systematic errors using the Apex2 suite of programs [28]. SHELXS-97 [29] was used to solve the structure using direct methods and SHELTXL6.14 [30], SHELXL2014 [31] and SHELXLE [32] were used for structure solving and refinement. All nonhydrogen atoms were refined anisotropically. $\mathrm{H}$ atoms were positioned geometrically and constrained to ride on their parent atoms, with carbon hydrogen bond distances of $0.95 \AA$ and $0.91 \AA$ for $\mathrm{NH}_{2}$ moieties, respectively. $U_{\text {iso }}(\mathrm{H})$ values were set to 1.2 times $U_{\text {eq }}(\mathrm{C} / \mathrm{N})$. The structure was refined as an inversion twin by full matrix least squares against $F^{2}$ with all reflections, the resultant twin ratio was $0.867(14)$ to $0.233(14)$.Crystal data are reported in Table 1. Drawings were made with Diamonds [33] and Mercury [34].

\subsubsection{Physical measurements}

The X-ray Powder diffractometryXRPD measurements were performed using a Panalytical X'Pert Pro diffractometer equipped with a $\mathrm{Cu}$ tube, a $\mathrm{Ge}(111)$ incident-beam monochromator $(\alpha=1.5406 \AA)$ and an X'Celerator detector. Data collection was carried out in the scattering angle range $2-60^{\circ}$ with a $0.00835^{\circ}$ step.

NMR spectra were recorded on a solid-state high-resolution Bruker DSX-500 spectrometer operating at $470.38 \mathrm{MHz}$ for ${ }^{19} \mathrm{~F}$ and on a BrukerDSX-300 spectrometer operating at $75.49 \mathrm{MHz}$ for ${ }^{13} \mathrm{C}$ with classical $4 \mathrm{~mm}$ probe heads allowing spinning rates up to10 $\mathrm{kHz} .{ }^{13} \mathrm{C}$ and ${ }^{19} \mathrm{~F}$ NMR chemical shifts are given relative to tetramethylsilane and fluorotrichloromethane, respectively (precision $0.5 \mathrm{ppm}$ ). The carbon spectrum was recorded by use of Cross-Polarization (CP) from protons (contact time $5 \mathrm{~ms}$ ) and MAS. Before recording the spectrum, it was checked that there was a sufficient delay between the scans to allow for a full relaxation of the protons. Fourier Transform Infrared (FTIR) spectra of powder samples were obtained using a Nicolet 5700 spectrophotometer from potassium bromide (KBr) pellets ( $2 \mathrm{mg}$ of sample in $200 \mathrm{mg}$ of $\mathrm{KBr}$ ). The number of scans was 32 . The 
scanning range was $4000-400 \mathrm{~cm}^{-1}$ and the resolution $2 \mathrm{~cm}^{-1}$. Differential Scanning Calorimetriy (DSC) measurements were made on a DSC Mettler Toledo with a HSS8 sensor. Prior to the measurements, the DSC was calibrated using indium and mercury. Perforated aluminum crucibles were used for analysis. The sample $(5.14 \mathrm{mg})$ was accurately weighed and then heated under nitrogen at a scan rate of $5^{\circ} \mathrm{C} \cdot \mathrm{min}^{-1}$ from -150 to $400^{\circ} \mathrm{C}$. The $\mathrm{C}, \mathrm{H}$ and $\mathrm{N}$ microanalyses were carried out with a Vario Elemental analyzer.

\section{Results and discussion}

\subsection{X-ray diffraction study.}

The main geometrical features of the different chemical entities of the coordination compound $\mathrm{ZnCl}_{2}\left(\mathrm{C}_{6} \mathrm{H}_{4} \mathrm{FNH}_{2}\right)_{2}$ are reported in Table 2. The asymmetric unit of $\mathrm{ZnCl}_{2}\left(\mathrm{C}_{6} \mathrm{H}_{4} \mathrm{FNH}_{2}\right)_{2}$ comprises a $\mathrm{Zn}(\mathrm{II})$ cation, two coordinated chlorine anions and two coordinated monodentate nitrogen 4-fluoroaniline ligands (Fig. 1). The zinc ion is tetracoordinated by two nitrogen atoms, $\mathrm{N} 1$ and $\mathrm{N} 2$, and two chlorine atoms, $\mathrm{Cl} 1$ and $\mathrm{Cl} 2$. The detailed geometry of the $\mathrm{ZnCl}_{2} \mathrm{~N}_{2}$ tetrahedron (Table 2) shows that the bond distances $(\mathrm{Zn}-\mathrm{N} 1=2.050$ (2) $\AA$, Zn-N2 =2.047 (2) $\AA, \mathrm{Zn}-\mathrm{Cl} 2=2.2579$ (7) $\AA$ and $\mathrm{Zn}-\mathrm{Cl} 3=2.2559$ (7) $\AA$ ) are similar to those reported for similar tetrahedral $\mathrm{Zn}$ (II) complexes [35-37]. The bond angles around the $\mathrm{Zn}$ atom vary between $106.92(7)$ and $114.65(9){ }^{\circ}$, indicating that the $\mathrm{ZnCl}_{2} \mathrm{~N}_{2}$ species have a slightly distorted tetrahedral geometry. This distortion is less pronounced than in e.g. 4-(3,5-diphenyl-1H-pyrazol-1-yl)-6-(piperidin-1-yl) pyrimidine dichlorozincate, where the bond angles around the $\mathrm{Zn}$ atom in the $\mathrm{ZnCl}_{2} \mathrm{~N}_{2}$ tetrahedron range from 79.5(1) to $116.1(1)^{\circ}[38]$ and in $\left[\mathrm{ZnCl}_{2}\left(\mathrm{C}_{4} \mathrm{H}_{14} \mathrm{~N}_{3}\right)\right] \mathrm{ClO}_{4}$, where the bond angles around the $\mathrm{Zn}$ atom vary between $86.904(3)$ and $128.06(3)^{\circ}[39]$. 
In the structural arrangement, the $\mathrm{ZnCl}_{2} \mathrm{~N}_{2}$ tetrahedra are interconnected via $\mathrm{N}-\mathrm{H} \cdots \mathrm{Cl}$ hydrogen bonds to form layers parallel to the $(a, b)$ plane (Fig. S1). The organic molecules are inserted between these layers and are interconnected through $\mathrm{C}-\mathrm{H} \cdots \mathrm{Cl}$ hydrogen bonds to form an infinite three-dimensional network (Fig. 2, Table 3).

Examination of the organic geometrical features (Table 2) shows that the 4fluoroaniline molecule exhibits a regular spatial configuration with $\mathrm{C}-\mathrm{C}$ and $\mathrm{C}-\mathrm{N}$ distances and C-C-C and C-C-N angles quite similar to those found in other fluoroaniline compounds $[37,40]$. It is worth noticing that no $\pi-\pi$ stacking interactions between neighboring aromatic rings are present in the structure, and only one $\mathrm{C}-\mathrm{H} \cdots \pi$ interaction towards them is observed. The $\mathrm{C}-\mathrm{H} \cdots \pi$, between $\mathrm{H} 3$ and $\mathrm{C} 10$ of one of the C-F units, features an $\mathrm{H} \cdots \mathrm{C}$ distance of 2.859 and a C $\cdots \mathrm{C}$ distance and $\mathrm{C}-\mathrm{H} \cdots \mathrm{C}$ angle of $3.677(4) \AA$ and $144.9^{\circ}$, respectively (symmetry operator for $\mathrm{C} 10: 1-x, 1-y,-1 / 2+z)$.

Comparing the structure of the title compound, bis(4fluoroaniline)dichloridozincate(1), with that of bis(3-fluoroaniline)dichloridozincate (2) [37], the $\mathrm{Zn}$ atom lies on a general position in (1), while it is located on a special position in (2). The $\mathrm{ZnCl}_{2} \mathrm{~N}_{2}$ tetrahedron of (2) is less distorted that in (1), with the bond angles around the $\mathrm{Zn}$ atom varying between $108.07(3)$ and $113.87(6)^{\circ}$. It is worth to note that in both structures layers are generated by $\mathrm{N}-\mathrm{H} \cdots \mathrm{Cl}$ hydrogen bonds, spreading parallel to the $(a, b)$ planes. The strengths of the $\mathrm{N}-\mathrm{H} \cdots \mathrm{Cl}$ hydrogen-bonds are comparable. For complex (2), the $\mathrm{N} \cdots \mathrm{Cl}$ distances are between 3.368 (1) and 3.371 (1) $\AA$, while in the title compound (1), these distances range between 3.371 (2) and 3.454 (2) $\AA$ (Table 3). In both compounds, the two chlorine atoms are acceptors of hydrogen bonds. The structure of complex (1) is stabilized by $\mathrm{N}-\mathrm{H} \cdots \mathrm{Cl}$ and $\mathrm{C}-\mathrm{H} \cdots \mathrm{Cl}$ interactions, while the hydrogen bond network of the second complex (2) is composed of $\mathrm{N}-\mathrm{H} \cdots \mathrm{Cl}$ and $\mathrm{C}-\mathrm{H} \cdots \mathrm{F}$ interactions [37]. The structure of (2) is characterized by the presence of fluorine-fluorine interactions with an F...F distance of 
2.888(1) $\AA$, which is smaller than the sum of the van der Waals radii of $2.94 \AA$. In the structure of (1), on the other hand, the shortest F...F distance is $2.957 \AA$, which is slightly longer than the sum of the van der Waals radii.

\subsection{X-ray powder diffraction}

The powder X-Ray diffraction pattern of the title compound is depicted in Fig. 3. Its peaks were indexed in the orthorhombic, $P c a 2_{1}$, cell obtained from the single crystal experiment using the program PANalytical X'Pert HighScore Plus (version2.2a) [41]. The absence of extra peaks confirms the purity of the whole sample.

\subsection{Optimized Geometry}

Full optimization has been carried out to confirm the convergence to the minimum of the total energy. Geometry has been optimized for an isolated molecule and is compared with the structural parameters obtained from the Cif file. Some selected calculated bond lengths and bond angles with the experimental ones obtained using the B3LYP method with LanL2DZ basis are listed in Table 2. As seen from Table 2, slight variations in the bond lengths and bond angles are observed such as N1-Zn1, Cl1-Zn1, C4-F1, N2-Zn1-Cl1, N2Zn1-Cl1. The discrepancies can be explained by the reason that the calculation applied to isolated molecule without any intermolecular interactions with neighboring molecules in the crystal lattice. So, root mean square deviation is used to compare consistency the theoretical and experimental results. The RMSDs of bond length and angles results are 0.223 and 0.304 , respectively. There are small deviations revealed that the optimized parameters are in agreement with the experimental values.

\subsection{Hirshfeld Surface Analysis}

The intermolecular interactions of the title compound are quantified using Hirshfeld surface analysis. This approach is a graphical tool for visualization and understanding of 
intermolecular interactions [42]. The Hirshfeld surface of the title compound, colored according to the atoms in contacts, is shown in Fig. 4. The intermolecular contacts, highlighted by conventional mapping of $d_{\text {norm }}$ on molecular Hirshfeld surfaces, are shown in Fig. S2. The red spots over the surface indicate the contacts involving in the hydrogen bonds. Furthermore, contacts were plotted with fingerprint plots (Fig. 5). This figure indicates that the contribution of contacts on the Hirshfeld surfaces are mainly of type $\mathrm{H} . . . \mathrm{Cl}(30.6 \%), \mathrm{H} . . . \mathrm{H}$ (24\%), C...H (20.4\%), H...F (17.9\%) while other contact types are minor (C...C, F...F and $\mathrm{Cl} . . . \mathrm{Cl})$.

The definition of contacts enrichment ratios was previously described [43, 44]. Hence, the proportion of random contacts $R_{\mathrm{XY}}$ between two chemical elements $\mathrm{X}$ and $\mathrm{Y}$ is introduced. The $R_{\mathrm{XY}}$ values are defined as if all contact types $\mathrm{X} \cdots \mathrm{Y}$ in the crystal packing were equidistributed between all chemical types and are obtained by probability products. Then, the enrichment ratio $E_{\mathrm{XY}}$ for a pair of elements $(\mathrm{X}, \mathrm{Y})$ is defined as the ratio between the proportion of actual contacts in the crystal and the theoretical proportion of equidistributed random contacts:

$$
E_{\mathrm{XY}}=C_{\mathrm{XY}} / R_{\mathrm{XY}}
$$

An enrichment ratio larger than unity reveals that a pair of elements has a high propensity to form contacts in crystals, while pairs which tend to avoid contacts with each other should yield an $E$ value lower than unity.

Enrichment ratios computed with software MoProViewer [45]. The polar Hn and hydrophobic Hc atoms are distinguished. Contacts with random Rxy proportions larger than 5\% are highlighted in bold as they represent contacts between atoms abundant on the Hirshfeld surface. Contacts with $R x y<2 \%$ are in italics (Table 4). The latter enrichments correspond to ratios of two numbers close to zero. The numbers in the last line represent the proportion of 
the chemical types on the Hirshfeld surface. Zn atom which represents only $2.7 \%$ of the surface content is omitted (Table 4).

Globally, $\mathrm{H} \ldots \mathrm{Cl}$ intermolecular interactions is the most abundant in the crystal packing (Fig. 6). There are indeed one $\mathrm{C}-\mathrm{H} \ldots \mathrm{Cl}$ and four $\mathrm{N}-\mathrm{H} \ldots \mathrm{Cl}$ hydrogen bonds in the crystal structure (Table 3, Fig. 5a). However, the $\mathrm{Hn} . . . \mathrm{Cl}$ contacts appear much more enriched than the $\mathrm{Hc} . . \mathrm{Cl}$ ones (Table 4), as the Hn atom are much more electropositive than Hc and are strongly attracted by the electronegative chlorine atoms.

The H...H contacts are the second most frequent interactions due to the abundance of hydrogen on the molecular surface (Fig. 5b), they are mostly of Hc...Hc type and are underrepresented $(E=0.8$, (Table 4$)$.

The C...H interactions (Fig. 5c) constitute the third most occurrent contacts and the H...Hc type appears over-represented (enrichment $E_{\mathrm{CH}}=1.4$ ), while C...Hn interactions between a hydrophobic and a polar atom are under-represented $(E=0.8)$.

The H...F hydrogen bonds account for $17.9 \%$ of the total Hirshfeld surface (Fig. 5d). The organic fluorine atom does not interact at all with Hn, while Hc...F contacts are largely overrepresented (enrichment $E_{\mathrm{HcF}}=1.7$ ). The organic fluorine interactions are favored with the hydrophobic atoms: F, C and Hc.

Globally, in Table 4, all contacts between charged atoms on one hand ( $\mathrm{Hn}$ and $\left.\mathrm{Cl}^{-}\right)$and hydrophobic atoms on the other hand (C, F, Hc) are disfavored, except for the pair $\mathrm{Cl}^{-} \ldots \mathrm{Hc}$, due to the weak electropositive character of Hc atoms. Self-contacts for charged atoms are as expected very disfavored $E\left(\mathrm{Cl}^{-} \ldots \mathrm{Cl}^{-}\right)=0.3$ and $E(\mathrm{Hn} \ldots \mathrm{Hn}=0.0)$; even the hydrophobic but weakly charged $\mathrm{Hc}$ atoms tend to avoid to interact with themselves $(E(\mathrm{HC} \ldots \mathrm{Hc})=0.8)$.

Globally the driving forces in the crystal packing formation are the $\mathrm{Hn}$...Cl-electrostatic attractions and the hydrophobic contacts involving the fluorophenyl group. The view along a 
axis in Fig. S3 [46] illustrates well translated molecules along the $\mathbf{b}$ axis that form layers of hydrophobic interactions and layers of polar hydrogen bonds.

\subsection{Quantum mechanical study}

Quantum chemical calculation was performed from the crystal data with DFT method at the 6-311++G(d,p) basis set for all atoms except for the cadmium the effective core potentials (ECPs) (LanL2dZ basis and ECPs built in) is used., The calculations were performed using Gaussian 03 program [47]. The band gap energy is a critical parameter in determining the kinetic stability of the molecule. The highest occupied molecular orbital (HOMO) and lowest occupied molecular orbital (LUMO) of the molecule are displayed in Fig. 7. The energies of HOMO and LUMO are -9.525 and $1.917 \mathrm{eV}$, respectively. The large HOMO-LUMO gap is $11.442 \mathrm{eV}$, implies high kinetic stability and low chemical reactivity, because it is energetically unfavorable to add electron to a high-lying LUMO, to extract electrons from low-lying HOMO [48]. In order to study their electronic structure, frontier molecular compositions for various types of atoms in the frontier molecular orbitals were expressed as the atomic orbital coefficient square sum in the type of atomic orbitals and corrected by normalizing the specific molecule orbital [49]. Orbital contribution investigation indicates that the composition of HOMO is mainly localized around the carbon, nitrogen and chlorine atoms. In contrast, the components of LUMO are mainly around the $\mathrm{ZnN}_{2} \mathrm{Cl}_{2}$ moiety.

3.6. NMR spectroscopy. The ${ }^{19}$ F MAS NMR spectrum of the title compound (Fig. S4) exhibits a broad peak at $-111 \mathrm{ppm}$. Its line width at half height, being much broader than expected for a single peak, indicates that it is composed of overlapping signals. Deconvolution of this peak gives two components at ca. -110.2 and $-112.3 \mathrm{ppm}$, indicating the presence of two different environments for the fluorine in the structure of the compound. This 
result proves that the asymmetric unit cell should contain two organic molecules and is in agreement with the crystallographic data.

The ${ }^{13} \mathrm{C}$ CP-MAS NMR spectrum of $\mathrm{ZnCl}_{2}\left(\mathrm{C}_{6} \mathrm{H}_{4} \mathrm{FNH}_{2}\right)_{2}$ is shown on Fig. S5. Only four peaks with different intensities and linewidths are resolved, which correspond to the twelve crystallographically independent carbon atoms. The four resolved peaks can be attributed to the four chemically distinct carbon atoms, with the fluorine bonded carbon atoms resonating at $156.5 \mathrm{ppm}$ and the hydrogen bonded $\mathrm{C}$ atoms at 121.2 and $113.9 \mathrm{ppm}$ (the lower field signal can be assigned to the $\mathrm{C}$ atom ortho to the $\mathrm{C}-\mathrm{F}$ group). The amine bonded $\mathrm{C}$ atom's signal is substantially shifted from its expected value, due to the metal coordination of the nitrogen atom. It is found at $132.5 \mathrm{ppm}$, a value more typical for a cation than a neutral aniline, which usually resonate at $>140 \mathrm{ppm}$ [50]. The higher linewidth of the signal at 156.5 ppm is probably due to the ${ }^{13} \mathrm{C}-{ }^{19} \mathrm{~F}$ coupling. The failure to resolve all the peaks can be attributed to the overlapping resonance signals.

Theoretical calculations were undertaken in order to assign the NMR resonances to the different crystallographically unequivalent atoms of the unit cell. The calculations were made on the two different organic molecules in the asymmetric unit after optimization of the positions of the protons. The theoretical chemical shifts were subtracted from those of the reference (tetramethylsilane with $\delta_{\exp }=0 \mathrm{ppm}$ for carbon) calculated at the same level of theory.

The results are listed on Table 5. Clearly, there is a relatively good agreement between the experimental and the theoretical values calculated after optimization of the positions of the protons, allowing unambiguously the attribution of the different NMR signals.

3.7. IR spectroscopy. The IR spectrum of crystalline $\mathrm{ZnCl}_{2}\left(\mathrm{C}_{6} \mathrm{H}_{4} \mathrm{FNH}_{2}\right)_{2}$ is shown in Fig. S6 and some important vibration modes with their experimental values are listed in Table 6. To 
assign the infrared spectrum, theoretical calculations have been carried out. The spectrum was calculated by the same method than the NMR chemical shifts. The result is shown on Fig. 8 . Four imaginary frequencies where found but with a reasonable value (between -10 and $50 \mathrm{~cm}^{-}$

${ }^{1}$ ). Such a low value can be due to the errors in the localization of the $\mathrm{C}, \mathrm{N}$ and F atoms by $\mathrm{X}$ ray. Even if there are some discrepancies, the calculated spectrum is very similar to the experimental one allowing a good correlation between the experimental and theoretical data as shown on Fig. S7. The most representative and characteristic vibrational modes of this compound can be compared to those of similar complexes [51-53]. In the high-frequency region, the broad bands between 3600 and $2500 \mathrm{~cm}^{-1}$ correspond to the valence vibrations of $\mathrm{N}-\mathrm{H}$ and $\mathrm{C}-\mathrm{H}$ groups [54], while the sharp peaks in the same region are associated with the C$\mathrm{H}$ stretching vibrations. The observed bands in the $1650-1100 \mathrm{~cm}^{-1}$ region can be attributed to the bending vibrations of the $\mathrm{N}-\mathrm{H}$ groups and to the valence vibrations of the $\mathrm{C}=\mathrm{C}$ double bonds of the aromatic ring and to the stretching and bonding modes of the 4-fluoroaniline ligand, $v(\mathrm{C}-\mathrm{C}), v(\mathrm{C}-\mathrm{N}), \delta(\mathrm{C}-\mathrm{H})$ and $\delta(\mathrm{N}-\mathrm{N})[55,56]$. The band related to the stretching mode of the C-F group is observed at $1017 \mathrm{~cm}^{-1}$ [57]. The bands between 1000 and $500 \mathrm{~cm}^{-1}$ are assigned to the out of plane bending modes $\gamma\left(\mathrm{C}_{\text {ary }}-\mathrm{H}\right), \gamma\left(\mathrm{C}_{\text {ary }}-\mathrm{C}_{\text {ary }}\right), \gamma\left(\mathrm{C}_{\text {ary }}-\mathrm{N}_{\text {ary }}\right)$ and $\gamma(\mathrm{N}-\mathrm{H})$ [58].

The comparison of the IR spectrum of the title compound with that of the pure amine (Fig. S6) shows, in particular, that the presence of the $\mathrm{ZnCl}_{2}$ shifts the bands related to the $\mathrm{NH}_{2}$ groups of the amine, situated at 3458,3398 and $3239 \mathrm{~cm}^{-1}$, at lower wavenumbers, 3298, 3244 and $3078 \mathrm{~cm}^{-1}$, respectively. This shift towards the low frequencies is attributed to the formation of hydrogen bonds $\mathrm{N}-\mathrm{H} . . . \mathrm{Cl}$ in the salt.

3.8. Differential Scanning Calorimetry measurements. The results of the DSC measurements carried out to characterize the thermal stability of the complex $\mathrm{ZnCl}_{2}\left(\mathrm{C}_{6} \mathrm{H}_{4} \mathrm{FNH}_{2}\right)_{2}$ are given in Fig. S8. During heating, the thermogram DSC shows an 
intense endothermic peak at $262.5^{\circ} \mathrm{C}$ (onset at $236.30^{\circ} \mathrm{C}$ ) attributed to melting of the crystalline compound, with an enthalpy of $249.97{\mathrm{~J} . \mathrm{g}^{-1}}^{-}$. The temperature of the melting point was confirmed by independent measurement using a Kofler benchhot-stage microscope. The absence of thermal accident before this temperature proves that the compound contains no water molecule, as revealed by X-rays diffraction study, and it does not exhibit a solid-tosolid phase transition within the temperature range $-150-262.5^{\circ} \mathrm{C}$.

\section{Conclusions}

The $\mathrm{Zn}$ (II) complex with the monodentate ligand 4-fluoroaniline, $\mathrm{ZnCl}_{2}\left(\mathrm{C}_{6} \mathrm{H}_{4} \mathrm{FNH}_{2}\right)_{2}$, was synthesized and characterized by various physico-chemical methods. At the structural level, the atomic arrangement of this material consists of inorganic layers built by the $\mathrm{ZnCl}_{2}\left(\mathrm{NH}_{2}\right)_{2}$ units interconnected via $\mathrm{N}-\mathrm{H} \cdots \mathrm{Cl}$ hydrogen bonds. The bodies of the organic entities are located between these layers and connect with each other via $\mathrm{C}-\mathrm{H} \cdots \mathrm{Cl}$ hydrogen bonds. The $\mathrm{Zn}$ atom has a slightly distorted tetrahedral geometry. The $\mathrm{F}$ atom of the 4-fluoroaniline ligand is not involved in hydrogen bonding. Investigation of intermolecular interactions and crystal packing via Hirshfeld surface analysis reveals that that $\mathrm{H}$... $\mathrm{Cl}$ intermolecular interactions are the most abundant in the crystal packing. These contacts constitute the mainly driving forces in the crystal packing formation. The enrichment ratio is a novel and powerful tool derived from the Hirshfeld contact surface analysis to determine which type of contacts are over-or under-represented in crystal packings. The band gap energy indicates that the title compound is kinetically stable. The ${ }^{13} \mathrm{C}$ and ${ }^{19} \mathrm{~F} \mathrm{CP}-\mathrm{MAS}$ NMR spectra are in agreement with the crystallographic data. The vibrational absorption bands were identified by infrared spectroscopy and DFT calculations allowed their attributions. On the basis of agreement between experimental and theoretical results, assignments of all observed bands were examined and proposed in this investigation. Differential Scanning Calorimetry (DSC) shows 
that this compound is stable up to $262.5^{\circ} \mathrm{C}$. The powder X-Ray diffraction pattern confirms the purity of the whole sample.

\section{Supplementary data}

Crystallographic data for the structural analysis have been deposited at the Cambridge Crystallographic Data Centre, CCDC No1407349. These data can be obtained free of charge via http://www.ccdc.cam.ac.uk/conts/retrieving.html, or from the CCDC, 12 Union Road, Cambridge, CB2 1EZ, UK: fax: (+44) 01223-336-033; e-mail: deposit@ccdc.cam.ac.

\section{Acknowledgment}

Thanks to Professor Matthias Zeller of Youngstown State University (USA) for his fruitful collaboration. The diffractometer was funded by NSF grat 0087120 , by Ohio Board of Reagents grant CAP-491, and by YSU. 


\section{References}

[1] B. F. Huskins, R. Robson, Design and construction of a new class of scaffolding-like materials comprising infinite polymeric frameworks of 3D-linked molecular rods. A reappraisal of the zinc cyanide and cadmium cyanide structures and the synthesis and structure of the diamond-related frameworks $\left[\mathrm{N}\left(\mathrm{CH}_{3}\right)_{4}\right]\left[\mathrm{CuIZnII}(\mathrm{CN})_{4}\right]$ and $\mathrm{CuI}\left[4,4\right.$, 4",4"'-tetracyanotetraphenylmethane]BF4. $\mathrm{xC}_{6} \mathrm{H}_{5} \mathrm{NO}_{2}$, J. Am. Chem. Soc. 112 (1990) 1546-1554.

[2] W. Kobel, M. Hanack, Bis axially coordinated (phthalocyaninato)ruthenium(II) compounds, Inorg. Chem. 25 (1986) 103-107.

[3] M. Inoue, M. Kubo, Magnetic interaction in metal complexes with bridging nitrogenheterocyclic ligands, Coord. Chem. Rev. 21 (1976) 1-27.

[4] O-S. Jung, C. G. Pierpont, Photomechanical Polymers. Synthesis and Characterization of a Polymeric Pyrazine-Bridged Cobalt Semiquinonate-Catecholate Complex, J. Am. Chem. Soc. 116 (1994) 2229-2230.

[5] D. W. Smith, Chlorocuprates (II), Coor. Chem. Rev. 21 (1976) 93-158.

[6] J. Tao, X. Yin, L. F. Jiang, R. B. Huang, L. S. Zheng, Syntheses and crystal structures of two novel zinc(II) coordination polymers, Eur. J. Inorg. Chem. 14 (2003) 26782682. 
[7] K. Bhar, S. Khan, J. S. Costa, J. Ribas, O. Roubeau, P. Mitra, B. K. Ghosh, Crystallographic Evidence for Reversible Symmetry Breaking in a Spin-Crossover d7 Cobalt(II) Coordination Polymer, Angew. Chem. Int. Ed. 51 (2012) 2142-2145.

[8] P. A. Vigato, S. Tamburini, Advances in acyclic compartmental ligands and related complexes, Coord. Chem. Rev. 252 (2008) 1871-1995.

[9] C. Ruizperez, J. G. Platas, H. Lotter, L. Lezama, X. Solans, S. Dominguez, P. M. Zarza, M. J. Rocio, M. S. Palacios, P. Gili, structutre and properties of $\mathrm{Cu}(\mathrm{II})$ Oxypropiophenone-Salicylhydrazide)(2,2'-bipyridyl) $\quad[\mathrm{Cu}(\mathrm{ohp}$-shz)(bipy) $\quad$ and $\mathrm{Cu}(\mathrm{II})$ (o-hydroxypropiophenone-salicylhydrazide) (2,2'-bipyridylamine) monohydrate [Cu(ohp-shz)(bipyam) $\mathrm{H}_{2} \mathrm{O}$, Inorg. Chim. Acta. 255 (1997) 139-148.

[10] L. H. Uppadine, J. P. Gisselbrecht, J. M. Lehn, Protonic modulation of redox properties in ionisable [2 2] grid-like metalloarrays, Chem. Commun. Issue 6 (2004) 718-719.

[11] L. H. Uppadine, J. M. Lehn, Three-Level Synthetic Strategy Towards Mixed-Valence and Heterometallic [2 2] Gridlike Arrays, Angew. Chem., Int. Ed. 43 (2004) 240-243. 
[12] S. Banerjee, S. Mondal, S. Sen, S. Das, D. L. Hughes, C. Rizzoli, C. Desplanches, C. Mandal, S. Mitra, Four new dinuclear Cu(II) hydrazone complexes using various organic spacers: syntheses, crystal structures, DNA binding and cleavage studies and selective cell inhibitory effect towards leukemic and normal lymphocytes, Dalton Trans. 4 (2009) 6849-6860.

[13] R. Gaur, L. Mishra, Synthesis and Characterization of Ru(II)-DMSO-Cl-Chalcone Complexes: DNA Binding, Nuclease, and Topoisomerase II Inhibitory Activity, Inorg. Chem. 51 (2012) 3059-3070.

[14] J. Y. Lee, O. K Farha., J. Roberts, K. A. Scheidt, S. T. Nguyen, J. T. Hupp, Metalorganic framework materials as catalysts, Chem. Soc. Rev. 38 (2009) 1450-1459.

[15] D. P. Singh, D. S. Raghuvanshi, K. N. Singh, V. P. Singh, Synthesis, characterization and catalytic application of some novel binuclear transition metal complexes of bis-(2acetylthiophene) oxaloyldihydrazone for $\mathrm{C} \mathrm{N}$ bond formation, J. Mol. Catal. A: Chem. 379 (2013) 21-29.

[16] V. P Singh., K. Tiwari, M. Mishra, N. Srivastava, S. Saha, 5-[\{(2-Hydroxynaphthalen1-yl) methylene $\}$ amino] pyrmidine-2, $4(1 \mathrm{H}, 3 \mathrm{H})$-dione as $\mathrm{Al} 3+$ selective colorimetric and fluorescent chemosensor, Sens. Actuators, B182 (2013) 546-554.

[17] A. Sahana, A. Banerjee, S. Das, S. Lohar, D. Karak, B. Sarkar, S. K. Mukhopadhyay, A. K. Mukherjee, D. Das, A naphthalene-based Al 3+ selective fluorescent sensor for living cell imaging, Org. Bio. Chem. 9 (2011) 5523- 5529.

[18] A. S. Fouda, M.M. Gouda, S. I. Abd El-Rahman, Hydroxy acetophenone-aroyl hydrazone derivatives as corrosion inhibitors for $\mathrm{Cu}$ dissolution in HNO3 solution. Bull. Korean Chem. Soc. 21 (2000) 1085-1089. 
[19] R. R. Crichton, Chapter 4 - Biological Ligands for Metal Ions, Biol. Inorg. Chem. 2 (2012) 69-89.

[20] M. Ben Nasr, E. Jeanneau, C. Ben Nasr, Crystal Structure of $\mathrm{ZnCl}_{3}$ (Methyl-(2Pyridin-2-yl-Ethyl)-Ammonium), J. Anal. Chem. 6 (2015) 189-195.

[21] M. Ben Nasr, F. Lefebvre, C. Ben Nasr, Synthesis, Crystal Structure and Infrared Characterization of Bis(4-dimethylamino-pyridinium) Tetrachlorocuprate J. Anal. Chem. 6 (2015) 446-456.

[22] K. Kaabi, V. Ferretti, F. Lefebvre, C. Ben Nasr, Synthesis, structure and characterization of a new cadmium(II) iodide containing a tetradentate tripodal amine, J. Adv. Chem. 10 (2014) 2728-2736.

[23] W. Nbili, K. Kaabi, V. Ferretti, F. Lefebvre, C. Ben Nasr, Synthesis, structure and characterization of a new noncentrosymmetric $\mathrm{Zn}$ (II) complex with the 2-amino-5chloropyridine ligand (AClPy), J. Adv. Chem. 10 (2014) 3116-3126.

[24] K. Kaabi, M. Zeller, V. Ferretti, P. S. Pereira Silva, C. Ben Nasr, Synthesis, characterization and supramolecular structure of three new $\mathrm{Cu}(\mathrm{II})$ and $\mathrm{Ni}(\mathrm{II})$ complexes with the potentially bidentate ligand 2-amino-6-methylpyrimidin-4(1H)one (AMPO), Inorg. Chim. Acta. 388 (2012) 5259.

[25] S. Liu, W. Wang, J. Chen, J. Sun, Determination of Aniline and Its Derivatives in Environmental Water by Capillary Electrophoresis with On-Line Concentration, Int. J. Mol. Sci. 13 (2012) 6863-6872.

[26] J. M. Sontag (Ed.), Carcinogens in Industry and the Environment, Marcel Dekker, New York, 1981. 
[27] G. M. Williams, J. H. Weisburger, in: M.O. Amdur, J. Doull, C.D. Klassen (Eds.), Casarett and Doull's Toxicology, fourth ed. (Chapter 5), McGraw-Hill, New York, 1993.

[28] Bruker Apex2, Advanced X-ray Solutions Bruker AXS Inc., Madison, Wisconsin, USA. (2009).

[29] G. M. Sheldrick, A short history of SHELX, Acta Cryst. A64 (2008) 112-122.

[30] Bruker Advanced X-ray Solutions, SHELXTL (Version 6.14), Bruker AXS Inc., Madison, Wisconsin, USA, (2003).

[31] G. M. Sheldrick, SHELXL2013, University of Göttingen, Germany (2013).

[32] C. B. Hübschle, G. M. Sheldrick, B. Dittrich, ShelXle: a Qt graphical user interface for SHELXL, J. Appl. Cryst. 44 (2011) 1281-1284.

[33] K. Brandenburg 1998 DIAMOND version 2.0.

[34] C. F. Macrae, P. R. Edgington, P. McCabe, E. Pidcock, G. P. Shields, R. Taylor, M. Towler, J. van de Streek, Mercury: visualization and analysis of crystal structures, J. Appl. Cryst.39 (2006) 453-457.

[35] R. Novotna, Z. Travnicek, I. Popa, Synthesis and characterization of the first zinc (II) complexes involving kinetin and its derivatives: X-ray structures of 2-chloro-N6furfuryl-9-isopropyladenine and $\left.[\mathrm{Zn} \text { (kinetin) })_{2} \mathrm{Cl}_{2}\right] \cdot \mathrm{CH}_{3} \mathrm{OH}$, Inorg. Chim. Acta 363 (2010) 2071-2079. 
[36] W. Nbili, M. Zeller, F. Lefebvre, C. Ben Nasr, Synthesis, structure and characterization of two new $\mathrm{Zn}(\mathrm{II})$ and $\mathrm{Cd}(\mathrm{II})$ complexes with the bidentate ligand 2[(2-aminoethyl) amino]ethanaminium (AEEA), J. Mol. Struct. 1085 (2015) 37-44.

[37] M. Ben Nasr, E. Aubert, E. Espinosa, F. Lefebvre and C. Ben Nasr, Synthesis and physico-chemical studies of a novel coordination compound $\mathrm{ZnCl}_{2}\left(\mathrm{C}_{6} \mathrm{H}_{4} \mathrm{FNH}_{2}\right)_{2}$, J. Adv. Chem. 10 (2014) 2502-2511.

[38] M. B. Bushuev, K. A. Vinogradova, V. P. Krivopalov, E. B. Nikolaenkova, N. V. Pervukhina, D. Y. Naumov, M. I. Rakhmanova, E. M. Uskov, L. A. Sheludyakova, A.V. Alekseev, S.V. Larionov, Zinc(II) and cadmium(II) complexes based on 4-(3,5diphenyl-1H-pyrazol-1-yl)-6-(piperidin-1-yl)pyrimidine (L): Synthesis, structure, luminescence. Double lone pair- $\pi$ interactions in the structure of $\mathrm{ZnL}_{2} \mathrm{Cl}_{2}$, Inorg. Chim. Acta 371 (2011) 88-94.

[39] T. Naicker, T. Govender, H. G. Kruger, G. E. M. Maguire, (S)-Methyl 2-benzamido-3(3,4-dimeth-oxyphenyl)propanoate, ActaCryst. E68 (2012) o1.

[40] M. Ben Nasr, E. Aubert, E. Espinosa, F. Lefebvre and C. Ben Nasr, Synthesis and physico-chemical studies of a novel organo-metallic compound $\mathrm{CdCl}_{2}\left(\mathrm{C}_{6} \mathrm{H}_{4} \mathrm{FNH}_{2}\right)_{2}, \mathrm{~J}$. Mol. Struct. 1082 (2015) 162-169.

[41] X'Pert High Score Plus, PANalytical, Almeo, The Netherlands, 2006

[42] S. K. Wolff, D. J. Grimwood, J. J. McKinnon, D. Jayati-laka and M. A. Spackamn, “Crystal Explorer 3.0," University of Western Australia, Perth, 2007.

[43] C. Jelsch, K. Ejsmont, L. Huder, The enrichment ratio of atomic contacts in crystals, an indicator derived from the Hirshfeld surface analysis, IUCrJ 1 (2014) 119-128. 
[44] C. Jelsch, S. Soudani, C. Ben Nasr, Likelihood of atom-atom contacts in crystal structures of halogenated organic compounds, IUCrJ 2 (2015) 327-340.

[45] B. Guillot, MoProViewer: A molecule viewer for the MoPro charge density analysis program. Acta Cryst. A68 (2012) s204.

[46] A. Katrusiak, Crystallographic autostereograms 11 Color Plates for this article are on page 398, J. Mol. Graph. Model. 19 (2001) 363-367.

[47] M. J. Frisch, G. W. Trucks, H. B. Schlegel, G. E. Scuseria, M. A. Robb, J. R. Cheeseman, J. A. Jr. Montgomery, T. Vreven, K. N. Kudin, J. C. Burant, J. M. Millam, S. S. Iyengar, J. Tomasi, V. Barone, B. Mennucci, M. Cossi, G. Scalmani, N. Rega, G. A. Petersson, H. Nakatsuji, M. Hada, M. Ehara, K. Toyota, R. Fukuda, J. Hasegawa, M. Ishida, T. Nakajima, Y. Honda, O. Kitao, H. Nakai, M. Klene, X. Li, J. E. Knox, H. P. Hratchian, J. B. Cross, C. Adamo, J. Jaramillo, R. Gomperts, R. E. Stratmann, O. Yazyev, A. J. Austin, R. Cammi, C. Pomelli, J. W. Ochterski, P. Y. Ayala, K. Morokuma, G. A.Voth, P. Salvador, J. J. Dannenberg, V. G. Zakrzewski, S. Dapprich, A. D. Daniels, M. C. Strain, O. Farkas, D. K. Malick, A. D. Rabuck, K. Raghavachari, J. B. Foresman, J. V. Ortiz, Q. Cui, A. G. Baboul, S. Clifford, J. Cioslowski, B. B. Stefanov, G. Liu, A. Liashenko, P. Piskorz, I. Komaromi, R. L. Martin, D. J. Fox, T. Keith, M. A. Al-Laham, C. Y. Peng, A. Nanayakkara, M. Challacombe, P. M. W. Gill, B. Johnson, W. Chen, M. W. Wong, C. Gonzalez, Pople, J. A. Gaussian 03, Revision D.01,J. A. Gaussian, Inc., Wallingford CT,2004.

[48] Z. L. Wang, L. H. Wei, L. Y. Jin, J. P. Wang, Synthesis, Structure and Theoretical Calculation of Imidazolium 3, 5-Dinitrobenzoate, Chin. J. Struct. Chem. (2007) 26 $1423-1428$. 
[49] J. Zhang, B. Q. Yang, H. Y. Zhu, T. Li, Z. Y. Wen, Synthesis, Characterization, Crystal Structure and Quantum Chemical Calculation of Novel Compound1,3Dimethyl-2-ferrocenylmethylbenzimidazolium Iodide, Chin. J. Chem. (2006) 24 $637-641$.

[50] J. Reuben, Isotopic multiplets in the carbon-13 NMR spectra of aniline derivatives and nucleosides with partially deuterated amino groups: effect of intra- and intermolecular hydrogen bonding, J. Am. Chem. Soc. 109 (1987) 316-321.

[51] N. L. Calve, F. Romain, M. H. Limage, A. Novak, Etude par spectroscopie Raman et infrarouge des verres de pseudo-spin $\mathrm{Rb}_{0,65}\left(\mathrm{NH}_{4}\right)_{0,35} \mathrm{H}_{2} \mathrm{PO}_{4}$, J. Mol. Struct. 200 (1989) $131-147$.

[52] H. J. Ratajczak, Structural studies of some hydrogen-bonded ferroelectrics using polarized ir radiation, J. Mol. Struct. 3 (1969) 27-41.

[53] A. Navak, Vibrational studies of structural phase transitions in partially ordered solids, J. Mol. Struct. 217 (1990) 35-49.

[54] W. Smirani, C. Ben Nasr, M. Rzaigui, Synthesis and crystal structure of a new oethylphenylammonium triphosphate $\left[2-\mathrm{C}_{2} \mathrm{H}_{5} \mathrm{C}_{6} \mathrm{H}_{4} \mathrm{NH}_{3}\right] 3 \mathrm{H}_{2} \mathrm{P}_{3} \mathrm{O}_{10}$, Mat. Res. Bull. 39 (2004) 1103-1111. 
[55] K. Kaabi, A. Rayes, C. Ben Nasr, M. Rzaigui, F. Lefebvre, Synthesis and crystal sructure of a new dihydrogenomonophosphate $\left(4-\mathrm{C}_{2} \mathrm{H}_{5} \mathrm{C}_{6} \mathrm{H}_{4} \mathrm{NH}_{3}\right) \mathrm{H}_{2} \mathrm{PO}_{4}$, Mat. Res. Bull. 38 (2003) 741-747.

[56] A. Oueslati, C. Ben Nasr, A. Durif, F. Lefebvre, Synthesis and characterization of a new organic dihydrogen phosphate-arsenate: $\left[\mathrm{H}_{2}\left(\mathrm{C}_{4} \mathrm{H}_{10} \mathrm{~N}_{2}\right)\right]\left[\mathrm{H}_{2}(\mathrm{As}, \mathrm{P}) \mathrm{O}_{4}\right]_{2}$, Mat. Res. Bull. 40 (2005) 970-980.

[57] M. Arivazhagan, D. A. Rexalin, Spectrochim. Acta Part A Mol. Biomol. Spectrosc. 96 (2012) 668-676.

[58] A. Oueslati, A. Rayes, C. Ben Nasr, F. Lefebvre, Synthesis and characterization of 2amino-3-methylpyridinium dihydrogenomonoarsenate, Mat. Res. Bull. 40 (2005) $1680-1689$. 


\section{Figure captions}

Fig. 1

Asymmetric unit of $\mathrm{ZnCl}_{2}\left(\mathrm{C}_{6} \mathrm{H}_{4} \mathrm{FNH}_{2}\right)_{2}$ with the atom numbering scheme and thermal ellipsoids at $50 \%$ probability.

Fig. 2

A projection of the structure of $\mathrm{ZnCl}_{2}\left(\mathrm{C}_{6} \mathrm{H}_{4} \mathrm{FNH}_{2}\right)_{2}$ along the $a$-axis. The dotted lines indicate hydrogen bonds.

Fig. 3

Powder X-ray diffraction patterns of $\mathrm{ZnCl}_{2}\left(\mathrm{C}_{6} \mathrm{H}_{4} \mathrm{FNH}_{2}\right)_{2}$.

Fig.4

View of the Hirshfeld surface around the $\mathrm{Zn}\left(\mathrm{C}_{6} \mathrm{H}_{4} \mathrm{FNH}_{2}\right)_{2}$ moiety and surrounding molecules. Coloring according to the atoms contributing most to the electron density. Hc: grey, Hn: light blue, C: black, Cl: dark green, F: purple, Zn: red.

Fig. 5

2D Fingerprint plots of the title compound.

Fig. 6

Relative contributions to the Hirshfeld surface area for the various intermolecular contacts in the title complex.

Fig. 7

Frontier molecular orbitals (HOMO and LUMO).

Fig. 8

Calculated IR absorption spectrum of $\mathrm{ZnCl}_{2}\left(\mathrm{C}_{6} \mathrm{H}_{4} \mathrm{FNH}_{2}\right)_{2}$. 


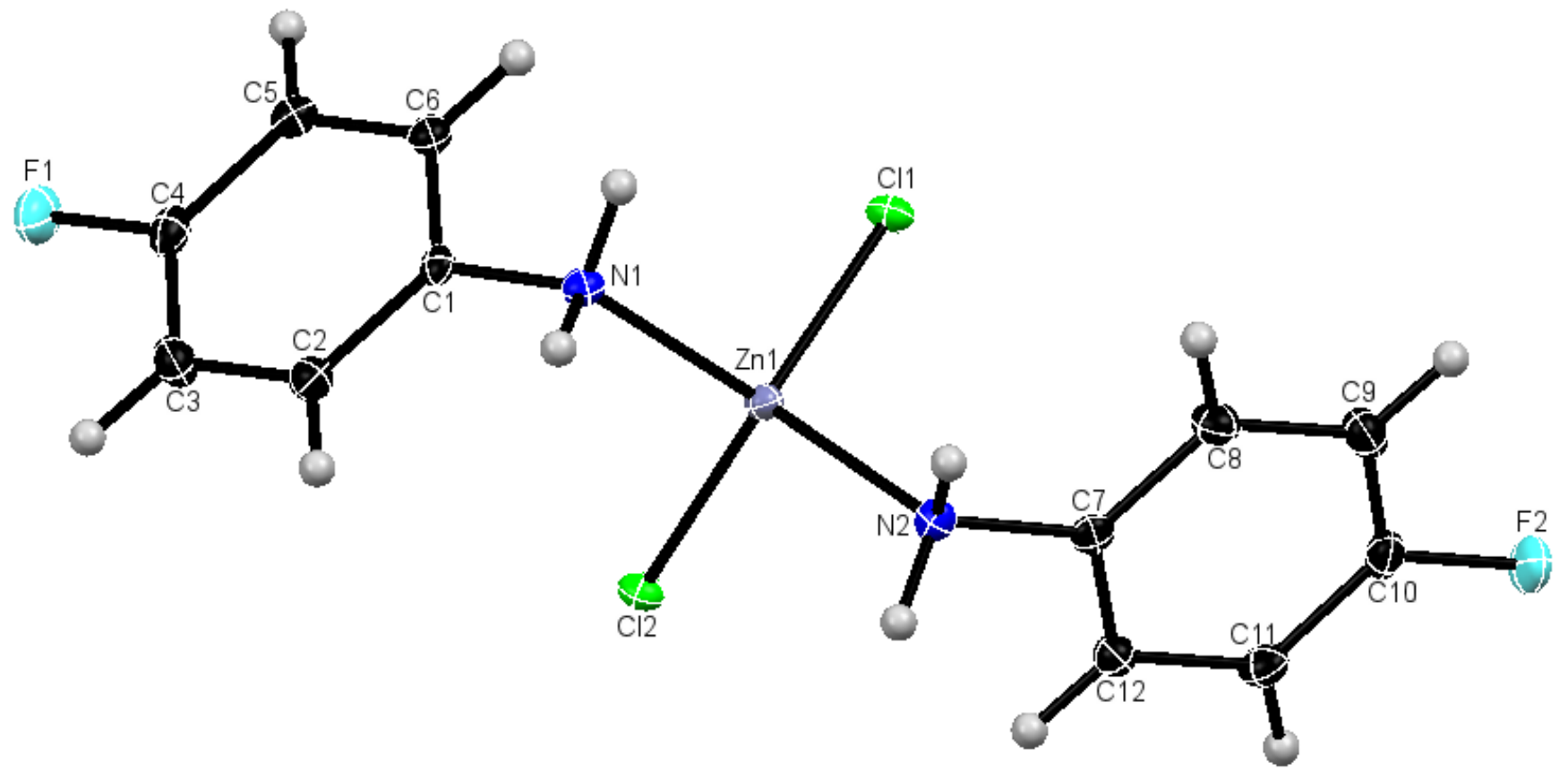

Fig. 1 


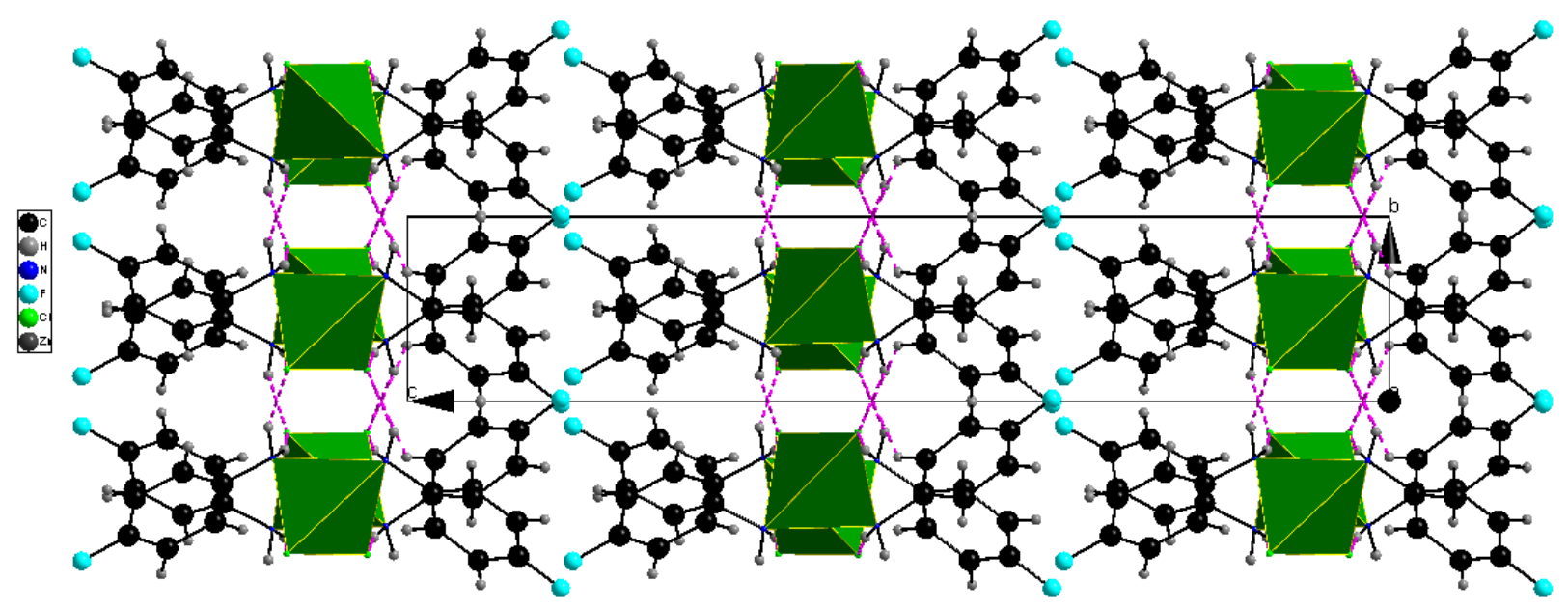

Fig. 2 


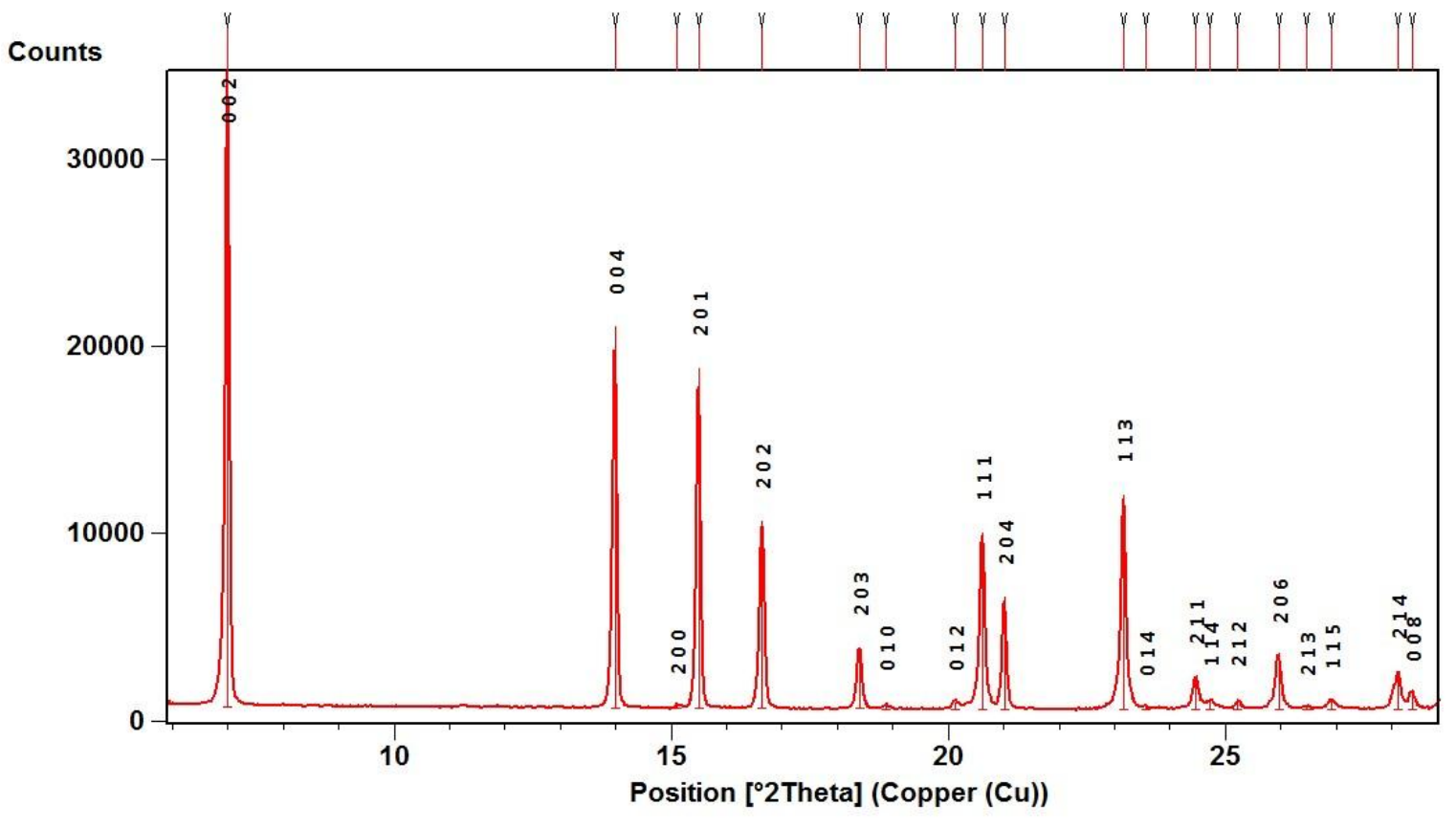

Fig. 3 


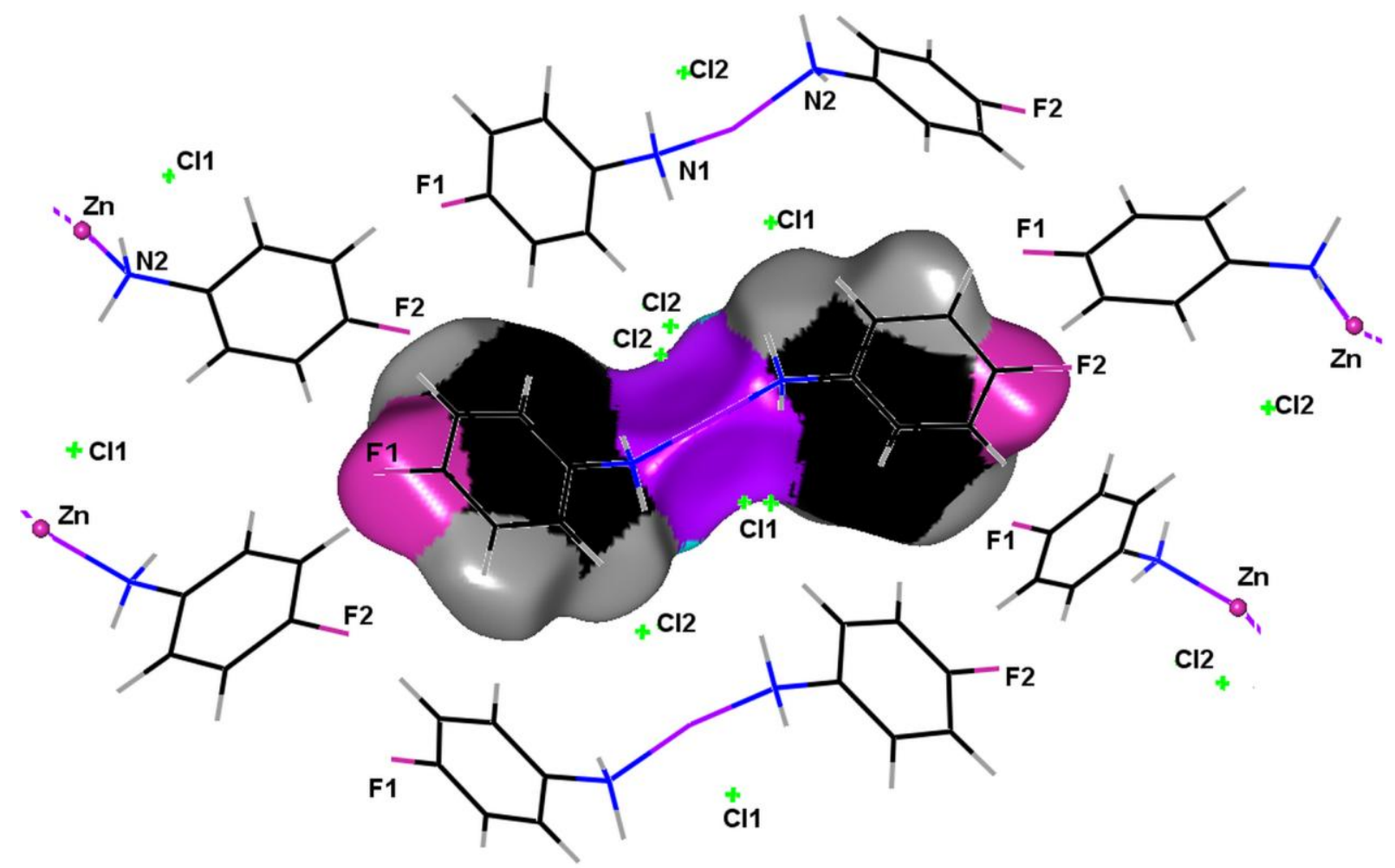

Fig. 4 


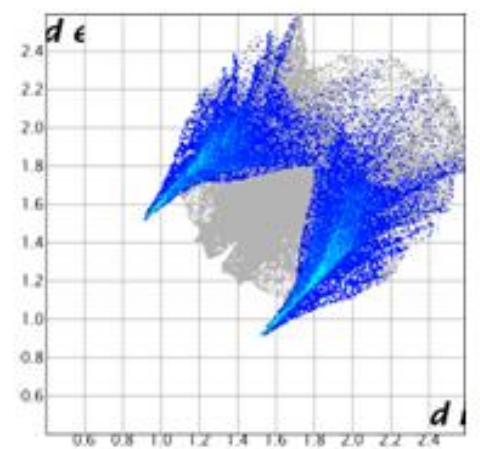

a) $\mathrm{H} . . \mathrm{Cl} / \mathrm{Cl} \ldots \mathrm{H}: 30.6 \%$

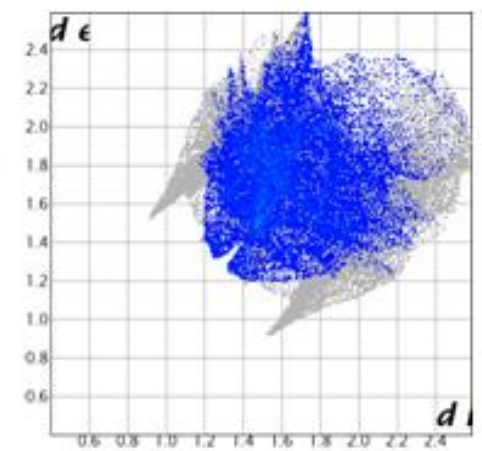

b) $\mathrm{H} \ldots \mathrm{H} / \mathrm{H} \ldots \mathrm{H}: 24 \%$

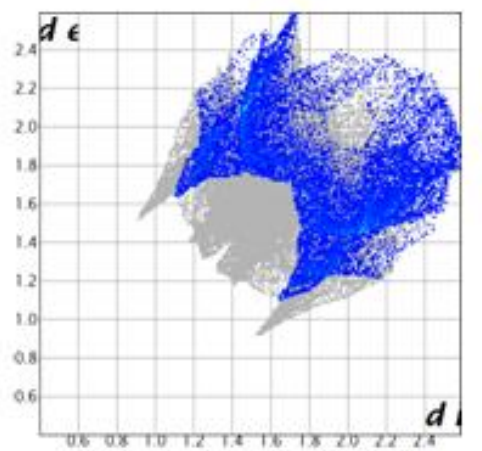

c) C...H/H...C: $20.4 \%$

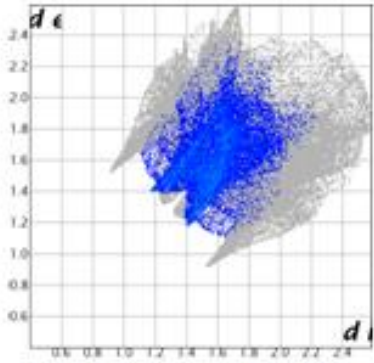

d) $\mathrm{H}$...F/F...H: $17.9 \%$

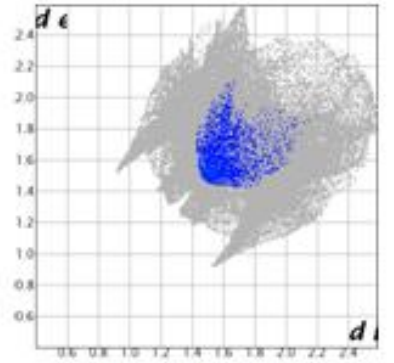

e) F...F : $2.7 \%$

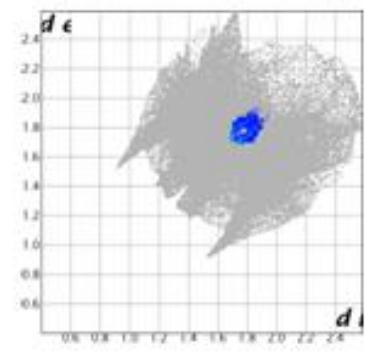

f) C...C: $1.5 \%$

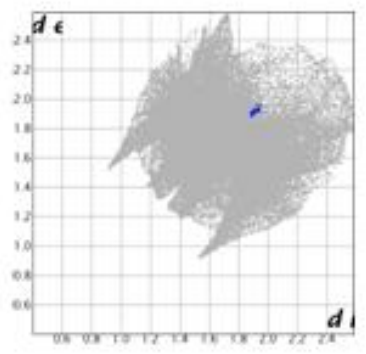

g) Cl...Cl: $0.1 \%$

Fig. 5 


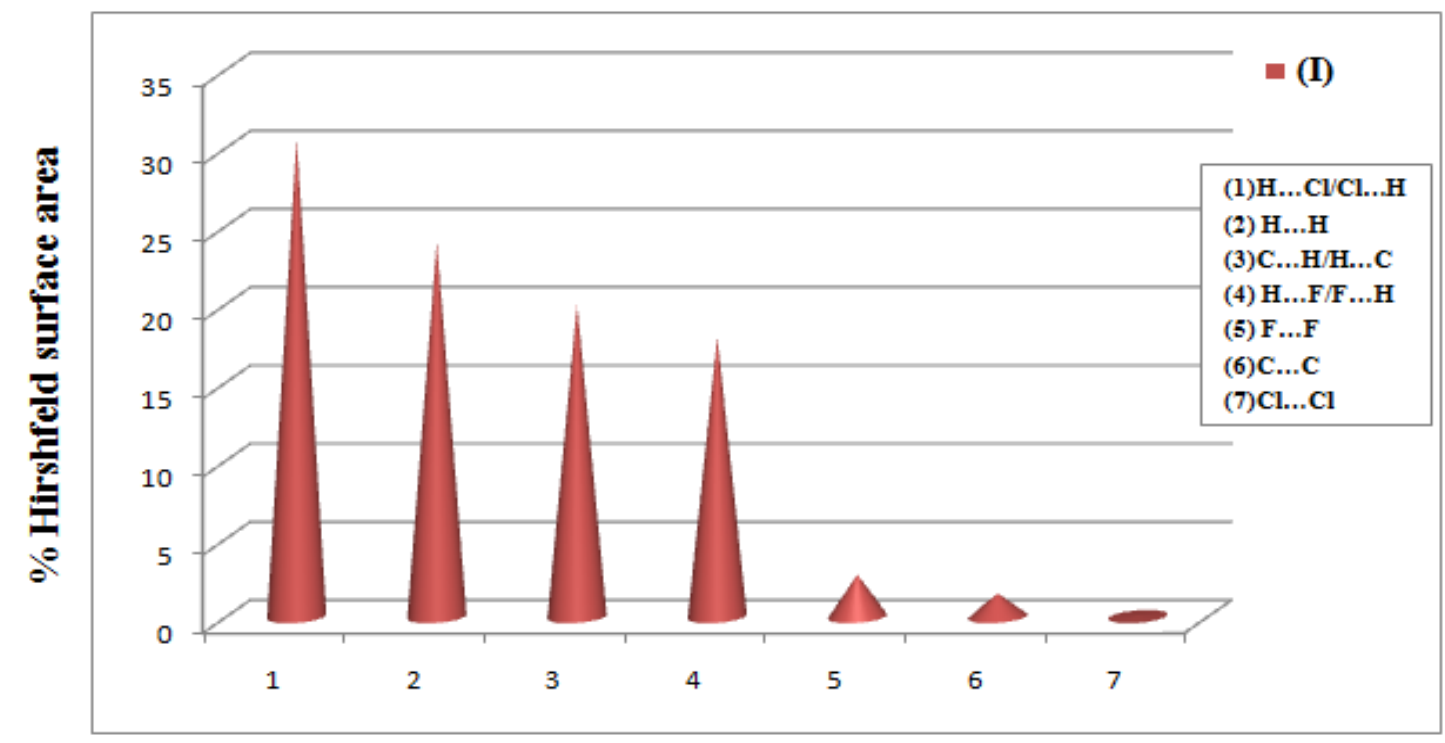

Interactions

Fig. 6 


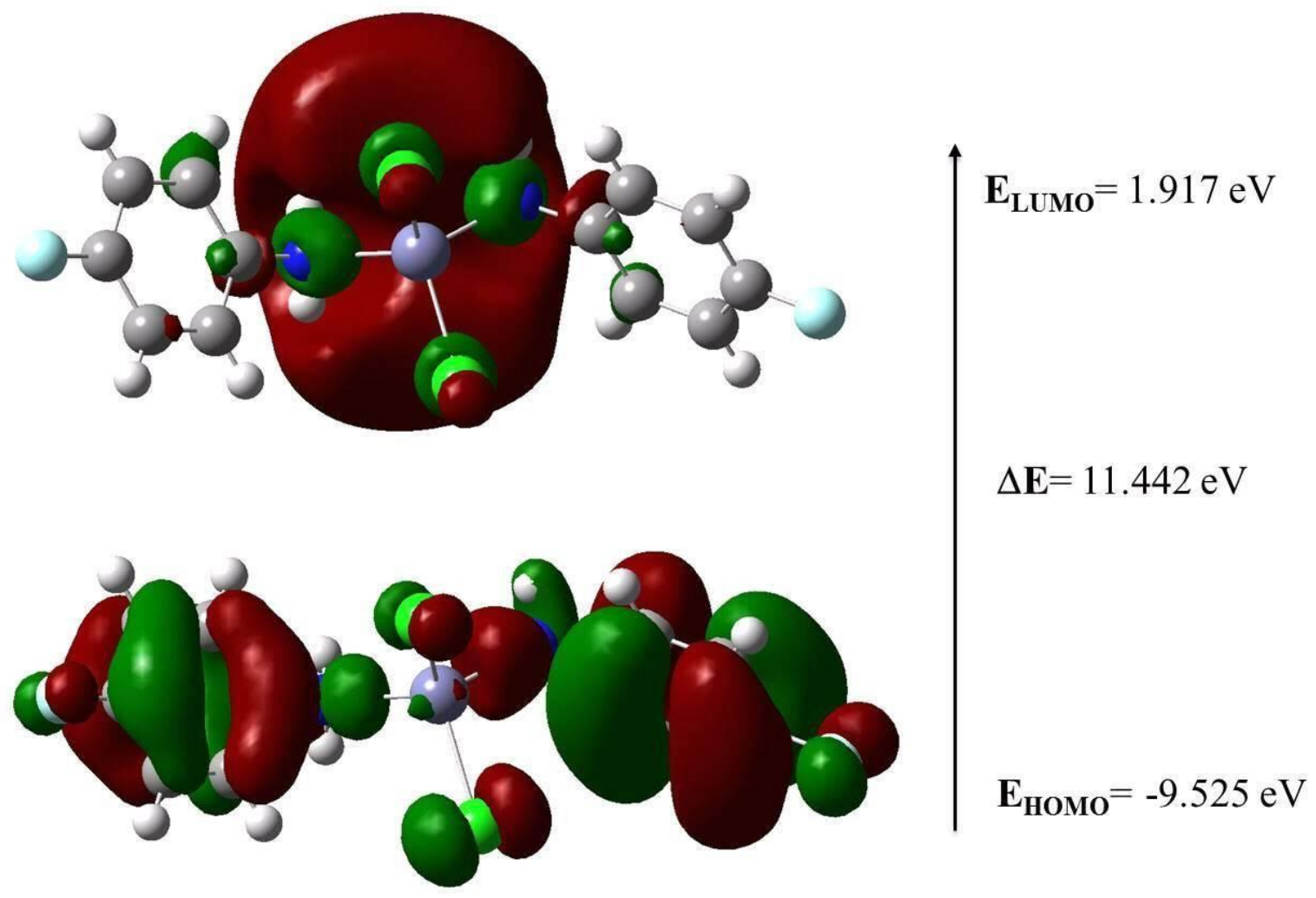

Fig. 7 


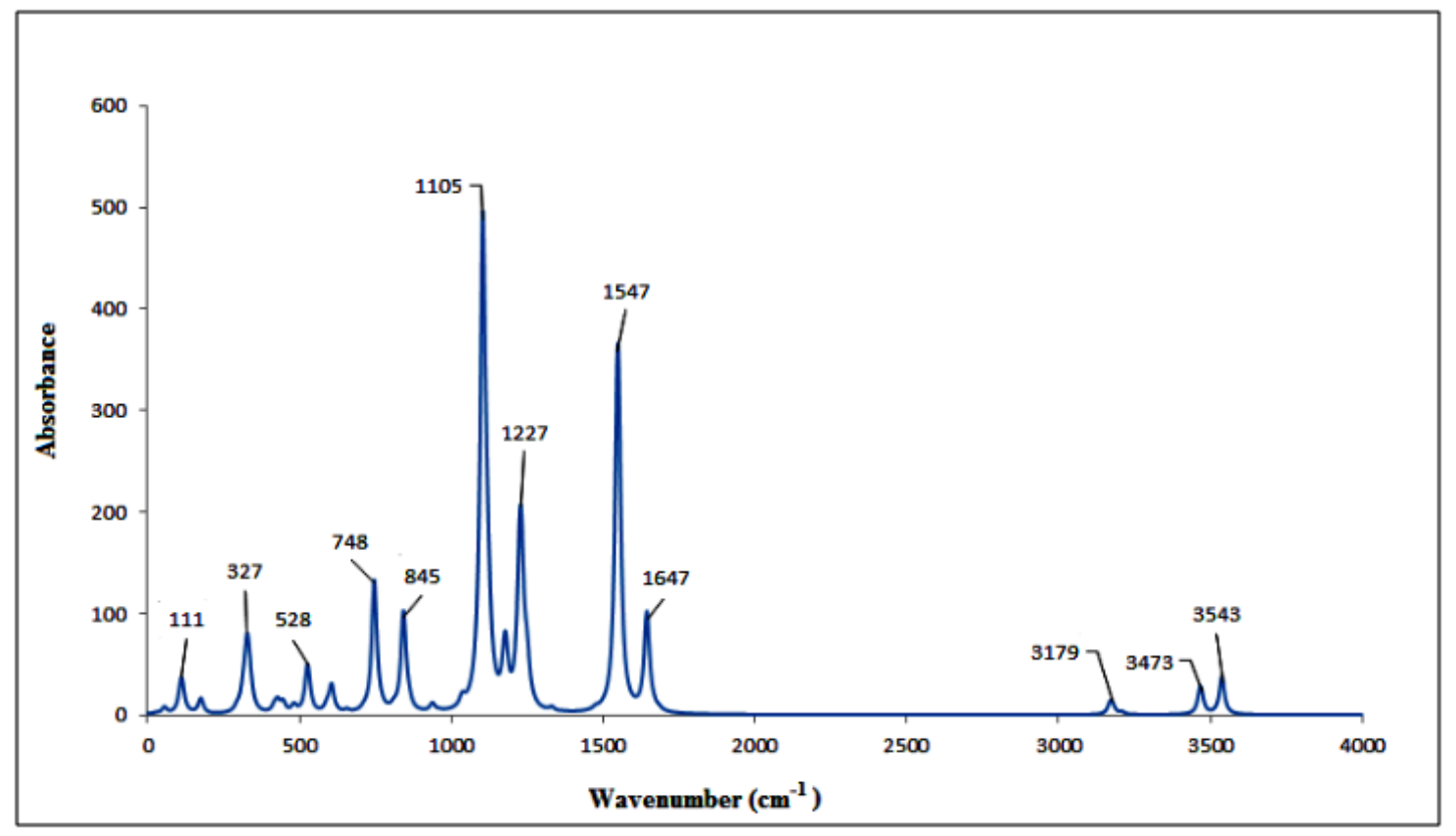

Fig. 8 
Table 1. Experimental details of $\mathrm{ZnCl}_{2}\left(\mathrm{C}_{6} \mathrm{H}_{4} \mathrm{FNH}_{2}\right)_{2}$.

\begin{tabular}{ll}
\hline Crystal data & \\
Chemical formula & $\mathrm{C}_{12} \mathrm{H}_{12} \mathrm{Cl}_{2} \mathrm{~F}_{2} \mathrm{~N}_{2} \mathrm{Zn}$ \\
$M_{\mathrm{r}}$ & 358.51 \\
Crystal system, spacegroup & Orthorhombic, $P c a 2_{1}$ \\
Temperature $(\mathrm{K})$ & 100 \\
$a, b, c(\AA)$ & $11.6152(18), 4.7047(7), 25.069(4)$ \\
$V\left(\AA^{3}\right)$ & $1369.9(4)$ \\
$Z$ & 4 \\
Radiation type & $\mathrm{Mo} \mathrm{K \alpha}$ \\
$\mu($ mm & $-1)$ \\
Crystal size $(\mathrm{mm})$ & 2.19 \\
Data collection & $0.55 \times 0.18 \times 0.12$ \\
No. of measured, independent and & \\
observed $[I>2 \sigma(I)]$ reflections & $8012,3473,3256$ \\
$R_{\text {int }}$ & \\
Refinement & $0.72,-0.33$ \\
$R\left[F^{2}>2 \sigma\left(F^{2}\right)\right], w R\left(F^{2}\right), S$ & 0.023 \\
No. of reflections & \\
No. of parameters & \\
$\Delta \rho_{\text {max }}, \Delta \rho_{\text {min }}\left(\mathrm{e} \AA^{-3}\right)$ & $0.025,0.063,1.05$ \\
\hline
\end{tabular}


Table 2. Selected bond distances and angles $\left(\AA^{\circ}{ }^{o}\right)$ and calculated geometric parameters of the title compound.

\begin{tabular}{|c|c|c|}
\hline Parameters & \multirow[t]{2}{*}{ XRD Data } & \multirow[t]{2}{*}{ Theoretical data } \\
\hline Bond lengths $(\AA)$ & & \\
\hline $\mathrm{N} 1-\mathrm{Zn} 1$ & $2.050(2)$ & 2.1717 \\
\hline $\mathrm{N} 2-\mathrm{Zn} 1$ & $2.047(2)$ & 2.1718 \\
\hline $\mathrm{Cl1}-\mathrm{Zn} 1$ & $2.2559(7)$ & 2.3125 \\
\hline $\mathrm{Cl} 2-\mathrm{Zn} 1$ & $2.2579(7)$ & 2.3129 \\
\hline $\mathrm{C} 1-\mathrm{C} 2$ & $1.388(4)$ & 1.4077 \\
\hline $\mathrm{C} 1-\mathrm{C} 6$ & $1.395(4)$ & 1.4107 \\
\hline $\mathrm{C} 1-\mathrm{N} 1$ & $1.447(3)$ & 1.4588 \\
\hline $\mathrm{C} 2-\mathrm{C} 3$ & $1.391(5)$ & 1.4061 \\
\hline $\mathrm{C} 3-\mathrm{C} 4$ & $1.382(4)$ & 1.3974 \\
\hline $\mathrm{C} 4-\mathrm{F} 1$ & $1.358(3)$ & 1.4022 \\
\hline $\mathrm{C} 4-\mathrm{C} 5$ & $1.378(4)$ & 1.4057 \\
\hline $\mathrm{C} 5-\mathrm{C} 6$ & $1.395(4)$ & 1.399 \\
\hline C9- $-\mathrm{C} 10$ & $1.381(4)$ & 1.3974 \\
\hline $\mathrm{C} 10-\mathrm{F} 2$ & $1.361(3)$ & 1.4022 \\
\hline $\mathrm{C} 10-\mathrm{C} 11$ & $1.375(4)$ & 1.3991 \\
\hline $\mathrm{C} 11-\mathrm{C} 12$ & $1.395(4)$ & 1.4056 \\
\hline $\mathrm{C} 7-\mathrm{C} 8$ & $1.382(4)$ & 1.4056 \\
\hline $\mathrm{C} 7-\mathrm{C} 12$ & $1.393(4)$ & 1.4107 \\
\hline $\mathrm{C} 7-\mathrm{N} 2$ & $1.451(3)$ & 1.4587 \\
\hline $\mathrm{C} 8-\mathrm{C} 9$ & $1.390(4)$ & 1.4061 \\
\hline \multicolumn{3}{|l|}{ Bond angles $\left(^{\circ}\right)$} \\
\hline $\mathrm{N} 2-\mathrm{Zn} 1-\mathrm{N} 1$ & $114.65(9)$ & 118.8288 \\
\hline $\mathrm{N} 1-\mathrm{Zn} 1-\mathrm{Cl1}$ & $108.97(7)$ & 101.066 \\
\hline $\mathrm{N} 1-\mathrm{Zn} 1-\mathrm{Cl} 2$ & $106.92(7)$ & 100.5675 \\
\hline $\mathrm{N} 2-\mathrm{Zn} 1-\mathrm{Cl1}$ & $108.76(7)$ & 100.6476 \\
\hline $\mathrm{N} 2-\mathrm{Zn} 1-\mathrm{Cl} 2$ & $108.43(7)$ & 100.9318 \\
\hline $\mathrm{Cl} 1-\mathrm{Zn} 1-\mathrm{Cl} 2$ & $108.97(3)$ & 136.7694 \\
\hline $\mathrm{C} 2-\mathrm{C} 1-\mathrm{C} 6$ & $120.4(3)$ & 120.5995 \\
\hline $\mathrm{C} 2-\mathrm{C} 1-\mathrm{N} 1$ & $120.2(2)$ & 120.1586 \\
\hline $\mathrm{C} 6-\mathrm{C} 1-\mathrm{N} 1$ & $119.3(2)$ & 119.2176 \\
\hline $\mathrm{C} 1-\mathrm{C} 2-\mathrm{C} 3$ & $119.7(3)$ & 120.0363 \\
\hline $\mathrm{C} 4-\mathrm{C} 3-\mathrm{C} 2$ & $119.1(3)$ & 118.3008 \\
\hline $\mathrm{F} 1-\mathrm{C} 4-\mathrm{C} 5$ & $118.8(3)$ & 118.6073 \\
\hline $\mathrm{F} 1-\mathrm{C} 4-\mathrm{C} 3$ & $118.9(3)$ & 118.5822 \\
\hline $\mathrm{C} 5-\mathrm{C} 4-\mathrm{C} 3$ & $122.3(3)$ & 122.8105 \\
\hline $\mathrm{C} 4-\mathrm{C} 5-\mathrm{C} 6$ & $118.5(3)$ & 118.5897 \\
\hline $\mathrm{C} 1-\mathrm{C} 6-\mathrm{C} 5$ & $120.1(3)$ & 119.6596 \\
\hline $\mathrm{F} 2-\mathrm{C} 10-\mathrm{C} 11$ & $118.6(3)$ & 118.6052 \\
\hline $\mathrm{F} 2-\mathrm{C} 10-\mathrm{C} 9$ & $118.6(3)$ & 118.5848 \\
\hline $\mathrm{C} 11-\mathrm{C} 10-\mathrm{C} 9$ & $122.8(3)$ & 122.81 \\
\hline $\mathrm{C} 10-\mathrm{C} 11-\mathrm{C} 12$ & $118.7(3)$ & 118.5891 \\
\hline
\end{tabular}




\begin{tabular}{|l|l|l|}
\hline C7-C12-C11 & $119.4(2)$ & 119.6609 \\
\hline C8-C7-C12 & $120.8(3)$ & 120.599 \\
\hline C8-C7-N2 & $119.9(2)$ & 120.1568 \\
\hline C12-C7-N2 & $119.3(2)$ & 119.2197 \\
\hline C7-C8-C9 & $120.1(3)$ & 120.0355 \\
\hline C10-C9-C8 & $118.2(3)$ & 118.3019 \\
\hline
\end{tabular}


Table 3. Hydrogen-bond geometry $\left(\AA{ }^{\circ}{ }^{\circ}\right)$.

\begin{tabular}{|l|l|l|l|l|}
\hline $\boldsymbol{D}-\mathbf{H} \cdots \boldsymbol{A}$ & $\boldsymbol{D}-\mathbf{H}$ & $\mathbf{H} \cdots \boldsymbol{A}$ & $\boldsymbol{D} \cdots \boldsymbol{A}$ & $\boldsymbol{D}-\mathbf{H} \cdots \boldsymbol{A}$ \\
\hline $\mathrm{C} 6-\mathrm{H} 6 \cdots \mathrm{Cl} 2^{\mathrm{i}}$ & 0.95 & 2.86 & $3.554(3)$ & 131 \\
\hline $\mathrm{N} 1-\mathrm{H} 1 A \cdots \mathrm{Cl} 2^{\mathrm{ii}}$ & 0.91 & 2.62 & $3.418(2)$ & 147 \\
\hline $\mathrm{N} 1-\mathrm{H} 1 B \cdots \mathrm{Cl} 2^{\mathrm{iii}}$ & 0.91 & 2.57 & $3.454(2)$ & 163 \\
\hline $\mathrm{N} 2-\mathrm{H} 2 A \cdots \mathrm{Cl} 1^{\mathrm{ii}}$ & 0.91 & 2.55 & $3.371(2)$ & 151 \\
\hline $\mathrm{N} 2-\mathrm{H} 2 B \cdots \mathrm{Cl} 1^{\mathrm{iv}}$ & 0.91 & 2.53 & $3.411(2)$ & 162 \\
\hline
\end{tabular}

Symmetry codes: (i) $\mathrm{x}-1 / 2,-\mathrm{y}+2$, $\mathrm{z}$; (ii) $\mathrm{x}, \mathrm{y}-1$, $\mathrm{z}$; (iii) $\mathrm{x}-1 / 2,-\mathrm{y}+1$, $\mathrm{z}$; (iv) $\mathrm{x}+1 / 2,-\mathrm{y}+1$, $\mathrm{z}$. 
Table 4. Chemical proportions on the Hirshfeld surface and major interaction types.

The enrichment ratio of contacts highlights if interactions are over or under-represented in the crystal as compared to equiprobable contacts occurring with the same chemical content on the surface.

\begin{tabular}{|l|l|l|l|l|l|}
\hline Enrichment & Cl & C & F & Hc & Hn \\
\hline Cl & 0.3 & \multicolumn{4}{|l|}{} \\
\hline C & $\mathbf{0 . 2}$ & 1.2 & \multicolumn{4}{|l|}{} \\
\hline F & 0.0 & 1.2 & 1.5 & & \\
\hline Hc & $\mathbf{1 . 2}$ & $\mathbf{1 . 4}$ & $\mathbf{1 . 7}$ & $\mathbf{0 . 8}$ & \\
\hline Hn & 3.9 & 0.8 & 0.0 & 0.1 & 0.0 \\
\hline Surface \% & 17.9 & 25.6 & 10.4 & 31.5 & 11.7 \\
\hline
\end{tabular}


Table 5. Chemical shift values of the carbon atoms in $\mathrm{ZnCl}_{2}\left(\mathrm{C}_{6} \mathrm{H}_{4} \mathrm{FNH}_{2}\right)_{2}$.

\begin{tabular}{|c|c|c|}
\hline Atom & $\delta_{\text {th }}(\mathbf{p p m})$ & $\delta_{\exp }(\mathrm{ppm})$ \\
\hline \multirow[t]{2}{*}{ C-N } & 140.1 & \multirow[t]{2}{*}{132.5} \\
\hline & 139.5 & \\
\hline \multirow{4}{*}{ C-ortho } & 127.5 & \multirow{4}{*}{121.2} \\
\hline & 128.6 & \\
\hline & 126.1 & \\
\hline & 128.7 & \\
\hline \multirow{4}{*}{ C-meta } & 122.0 & \multirow[t]{4}{*}{113.9} \\
\hline & 122.9 & \\
\hline & 121.3 & \\
\hline & 122.1 & \\
\hline \multirow[t]{2}{*}{$\mathrm{C}-\mathrm{F}$} & 170.6 & \multirow[t]{2}{*}{156.5} \\
\hline & 171.3 & \\
\hline
\end{tabular}


Table 6. Experimental vibrational frequencies $\left(\mathrm{cm}^{-1}\right)$ and assignments of the title compound

\begin{tabular}{l|l}
\hline Assignments & Experimental $\left(\mathbf{c m}^{-\mathbf{1})}\right.$ \\
\hline$v \mathrm{~N}-\mathrm{H}+v \mathrm{C}-\mathrm{H}$ & $3600-2500$ \\
$v(\mathrm{~N}-\mathrm{H})+v \mathrm{C}=\mathrm{C}+v(\mathrm{C}-\mathrm{C})+v(\mathrm{C}-\mathrm{N})+\delta(\mathrm{C}-\mathrm{H})+\delta(\mathrm{N}-\mathrm{N})$ & $1650-1100$ \\
$v \mathrm{C}-\mathrm{F}$ & 1017 \\
$\gamma\left(\mathrm{C}_{\text {ary }}-\mathrm{H}\right)+\gamma\left(\mathrm{C}_{\text {ary }}-\mathrm{C}_{\text {ary }}\right)+\gamma\left(\mathrm{C}_{\text {ary }}-\mathrm{N}_{\text {ary }}\right)+\gamma(\mathrm{N}-\mathrm{H})$ & $1000-500$ \\
\hline
\end{tabular}



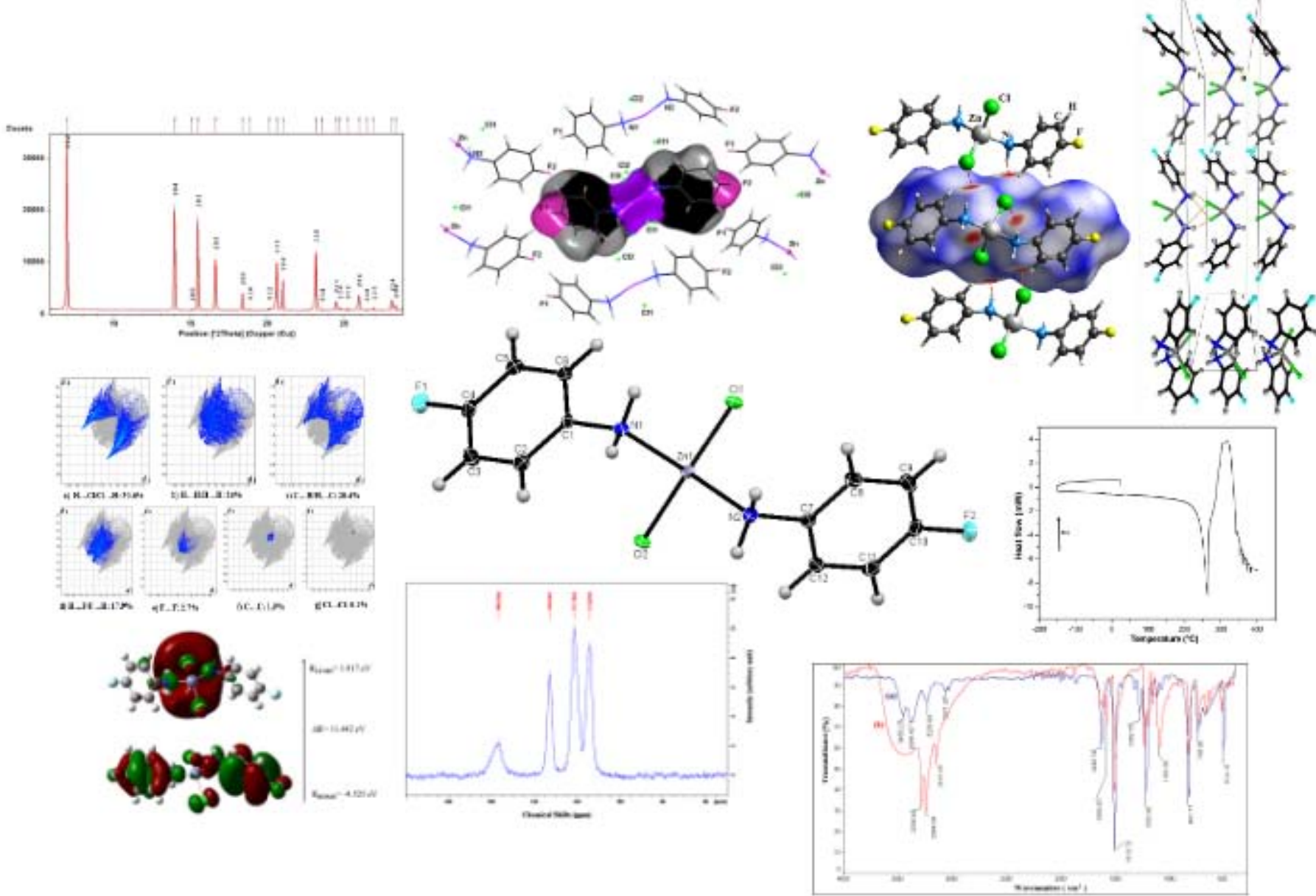